\title{
The Analysis of Hematological Parameters in Patients Presented with Allergic Rhinitis Symptoms
}

\author{
Ismail KARABULUT ${ }^{1}$, Hayriye KARABULUT ${ }^{2}$, Emre GUNBEY ${ }^{2}$, R. Murat KARASEN ${ }^{2}$ \\ ${ }^{1}$ Hacettepe University Faculty of Medicine, Department of Physiology \\ ${ }^{2}$ Ankara Kecioren Training and Research Hospital, Department of Otolaryngology, Ankara, TURKEY
}

\begin{abstract}
The aim of this study was to perform the analysis of hematological parameters in patients with allergic rhinitis symptoms. 181 patients underwent the skin prick test and completed the symptoms inquiry form were included in the study. We measured RBC (Red blood cells), Hb (hemoglobin), Htc (hemotocrit), WBC (white blood cells), PLT (platelet) and MPV (mean platelet volume) of the subjects. The relationship of the skin prick test positivity, allergic symptoms, severity and duration of symptoms, with the hematological parameters are analysed.

Hematologic parameters were in normal ranges in patients who presented with symptoms of chronic rhinitis. There was no correlation between skin prick test positivity and hematological parameters. In the Alergic rhinitis group, RBC and $\mathrm{Hb}$ were seen to be affected by duration of illness and not to be affected by allergen distribution. WBC was seen to decrease as the duration of illness prolonged in both allergic and non-allergic groups.

The presence of nasal symptoms was found to be associated with high RBC, Hb, Htc values. In the AR group, the RBC and $\mathrm{Hb}$ were found to have been affected by the duration of illness, and unaffected by the allergen distribution.
\end{abstract}

Keywords: Allergic rhinitis, Prick test, Hematologic parameters

\section{ÖZET}

\section{Alerjik Rinit Semptomları ile Başvuran Hastalarda Hematolojik Parametrelerin Analizi}

Çalışmanın amacı alerjik rinit semptomları ile başvuran hastalarda hematolojik parametrelerin analizini yapmaktı.

Deri prik testi yapılan ve semptom sorgulama formunu dolduran 181 hasta çalışmaya dahil edildi. Hastaların eritrosit, hemoglobin, hematokrit, lökosit, trombosit ve ortalama trombosit hacimleri ölçüldü. Deri prik test pozitifliği, alerjik semptomlar, semptomların şiddeti ve süresi ile hematolojik parametreler arasındaki ilişkilerin analizi yapııdı.

Alerjik semptomlar ile başvuran hastalarda hematolojik parametreler normal sınıllarda bulunmuştur. Deri prik test pozitifliği ile hematolojik parametreler arasında ilişki saptanmamıştır. Deri prik test sonucu pozitif grupta, eritrosit sayısı ve hemoglobin düzeyinin hastalık süresinden etkilendiği ancak alerjen dağılımından etkilenmediği saptanmıştır. Hem alerjik hem de alerjik olmayan gruplarda hastalık süresi uzadıkça lökosit sayııının azaldığı belirlenmiştir.

Nazal semptomların varlığı yüksek eritrosit, hemoglobin ve hemotokrit değerleriyle ilişkili bulunmuştur. Deri prik test sonucu pozitif grupta, eritrosit sayısı ve hemoglobin düzeyinin hastalık süresinden etkilendiği ancak alerjen dağıımından etkilenmediği saptanmıştır.

Anahtar Kelimeler: Alerjik rinit, Prick testi, hematolojik parametreler 


\section{INTRODUCTION}

Allergic Rhinit (AR) is characterized by a specific IgE-mediated hypersensitivity reaction, clinically arising following the exposure of the nasal mucosa to allergens. The main symptoms of AR are sneezing, nasal obstruction, nasal itching, post-nasal drip and smell disorders. Ocular symptoms like eye itching, congestion, lividity, pulmonary symptoms like cough, dyspnea, wheezing, and dermatological symptoms such as eruption, itching, rash, and urticaria can accompany nasal symptoms in patients with AR. The skin prick test is a widely used diagnostic skin test to indicate the IgE-related reaction in determination of allergens that lead to symptoms in patients with AR. ${ }^{1}$ These tests are cheap, easily applicable and yield a rapid result. The skin prick test can be applied using commercially available inhalent and food allergens, latex or drugs. ${ }^{2,3}$

The basic parameters obtained from full blood count are associated with blood cell counts (red blood cells (RBC), white blood cells (WBC), platelet (PLT)) and the sizes. WBC and PLT indicators affected by inflammatory and immunologic processes. The primary reason to assess the red blood cells is to check for anemia and to evaluate normal erythropoiesis. The number of RBC is determined by age, sex, altitude, exercise, diet, pollution, drug use, tobacco/nicotine use, kidney function, etc. The hemoglobin level indicates the amount of intracellular iron. The hematocrit $(\mathrm{Htc})$ is one of the most precise methods of determining the degree of anemia or polycythemia (excessive amount of red blood cells). ${ }^{4}$ Mean platelet volume (MPV) is considered a marker and determinant of platelet function since larger platelets are hemostatically more reactive than platelets of normal size, increasing the propensity to thrombosis. The biological and prognostic value of an increased MPV is still controversial and the reasons for increased platelet size are still unclear. ${ }^{4-7}$

The aim of this study was to investigate the levels of hematological parameters such as Hb, MPV in patients presented with chronic rhinitis symptoms. In addition, it has been analysed the relationships between these parameters and the skin prick test positivity, the presence and the severity of symptoms, the duration of disease.

\section{PATIENTS AND METHODS}

The data of 2005 patients who presented with the allergic rhinitis symptoms between January 2008 and November 2010 underwent the skin prick test, and completed the symptoms inquiry form were evaluated, retrospectively. 181 patients, who underwent complete blood count on the day of skin prick test, included into the study. Ages, gender, presence of nasal, ocular, pulmonary and dermatological symptoms were questioned. The patients were asked to choose one of the options that matched their complaints best (absent, mild, moderate and severe) in this form, the answers of which were presented as multiple choice. These options were scored as $0,1,2$ and 3 respectively in the assessment process. Diagnosis was made on the basis of history, physical examination findings, nasal endoscopic examination findings and the skin prick test results. Presence of sneezing, watery runny nose, nasal obstruction and itchy nose, presence of serous secretion in the nasal cavity, pale nasal mucosa, edematous, and pale or purple conchae, were interpreted in favour of AR. Coughing, dyspnea and wheezing were evaluated as respiratory symptoms. The skin prick test was not performed on patients who had been treated with the diagnosis of asthma, on those who had a suspicion of asthma, on those who had been using beta-blockers. Patients who were detected to have dermographism were also excluded from the study. Another exclusion criteria was patients with nasal septum deviations. Alyostal STIR (Stallegenes S.A.France) standard allergen extracts were used for the skin prick test. For the test, antihistamines had to have been withdrawn 10 days previously, $\mathrm{H}_{2}$-receptor blockers had to have been withdrawn 24 hours previously, and antidepressant drugs withdrawn 20 days previously. Allergen extracts that were taken in standard doses in Quick test applicators with 8 distinct edges were applied onto the skin after having cleaned the ventral part of the forearm with alcohol. The results were evaluated 15 minutes later. Histamine hydrochloride was used as positive control and isotonic $\mathrm{NaCl}$ was used as negative control. The validity criterion for the test was accepted as $>3 \mathrm{~mm}$ for positive control and $<3$ $\mathrm{mm}$ for negative control. Skin reaction against the allergen with an enduration of $>3 \mathrm{~mm}$ in diameter was accepted as a positive reaction. ${ }^{8}$ The most common 30 allergen extracts and positive and negative 
Table 1. Demographic features of the skin prick test $(+)$ and (-) subjects

\begin{tabular}{|lcc|}
\hline & Group I $(\mathrm{n}=94)$ & Group II $(\mathrm{n}=87)$ \\
\hline Age (years) Mean \pm Std dev & $32.6 \pm 11(14-59)$ & $33 \pm 11.8(17-65)$ \\
Gender $(M / F[\%])$ & $33 / 61(35.1 / 64.9 \%)$ & $38 / 49(43.7 / 56.3 \%)$ \\
$\begin{array}{l}\text { Duration of the disease } \\
\text { (years) Mean } \pm \text { Std dev }\end{array}$ & $6.3 \pm 5.9(0-32)$ & $5.3 \pm 5.5(0-30)$ \\
\hline
\end{tabular}

controls were applied using a total of 4 applicators onto the skin of forearm for the skin prick test. Two house dust mites, 3 fungal spores, 1 insect, 3 animal epithelia, 15 pollens and 6 food allergens were used.

Blood samples were drawn after a fasting period of 12 h. We measured RBC, Hb, Htc, WBC, PLT and MPV in a blood sample collected in EDTA. The measurements were performed immediately after blood sampling in order to prevent in vitro platelet activation. A Beckman Coulter Gen-S Hematology Analyzer was used for whole blood counts.

Statistical analysis was done using SPSS version 15. Categorical data is presented as percentages (frequencies), and quantitative data as mean and standart deviation values. For categorical data, Pearson chi-Square test was used to determine any significant association between the groups for different variables. For quantitative data, independent sample t test was used to determine any significant differences between the study groups. Linear regression analyses was used to determine the relationship between the hematological parameters and rhinitis duration, symptoms, age, gender, and allergen distrubition.

\section{RESULTS}

The demographic features of the patients included in the study have been presented in Table 1. Of the 181 patients, 94 were diagnosed as having allergic and 87 as non-allergic rhinitis. In patients who presented with symptoms of rhinitis, no significant difference was found between patients with positive and negative skin prick test results in terms of hematological parameters. The hematological data of patients with positive (Group I) and negative (Group II) skin prick test results have been displayed in Table 2.

Table 2. Hematologic parameters of two groups

\begin{tabular}{|llll|}
\hline & $\begin{array}{l}\text { Group I }(\mathrm{n}=94) \\
\text { Mean } \pm \text { Std dev }\end{array}$ & $\begin{array}{l}\text { Group II }(\mathrm{n}=87) \\
\text { Mean } \pm \text { Std dev }\end{array}$ & P value \\
\hline $\mathrm{WBC}(/ \mathrm{\mu L})$ & $7100 \pm 2200(4400-11900)$ & $7300 \pm 2175(44000-15100)$ & 0.31 \\
$\mathrm{RBC}\left(10^{6} / \mathrm{\mu L}\right)$ & $4.7 \pm 0.7(3.6-5.8)$ & $4.7 \pm 0.5(3.7-5.8)$ & 0.66 \\
$\mathrm{Hb}(\mathrm{g} / \mathrm{dL})$ & $13.8 \pm 3.0(9.2-16.9)$ & $13.9 \pm 2.0(9.5-16.9)$ & 0.6 \\
$\mathrm{Htc}(\%)$ & $39.7 \pm 7.7(27.7-48.9)$ & $39.8 \pm 4.7(28.3-49.8)$ & 0.82 \\
$\mathrm{PLT}\left(10^{3} / \mu \mathrm{L}\right)$ & $241 \pm 7.5(125-460)$ & $229.5 \pm 73.2(120-392)$ & 0.48 \\
$\mathrm{MPV}(\mathrm{fL})$ & $8.0 \pm 1.2(6.1-10.2)$ & $7.8 \pm 1.2(6.5-10.2)$ & \\
\hline
\end{tabular}


Table 3. The correlation between the duration of the disease and hematologic parameters in patients with nasal symptoms

\begin{tabular}{|llll|}
\hline & RBC & Hb & Htc \\
\hline Itchy nose $(n=122)$ & Rho: 0.296 & Rho: 0.302 & Rho: 0.296 \\
& p: 0.001 & p: 0.001 & p: 0.001 \\
Nasal obstruction $(n=129)$ & Rho: 0.279 & Rho: 0.243 & Rho: 0.231 \\
& p: 0.001 & p: 0.006 & p: 0.009 \\
Runny nose $(n=123)$ & Rho: 0.232 & Rho: 0.080 & Rho: 0.057 \\
Sneezing $(n=138)$ & p: 0.01 & p: 0.28 & p: 0.44 \\
Rho: 0.204 & Rho: 0.084 & Rho: 0.054 \\
Headache $(n=138)$ & p: 0.001 & p: 0.27 & p: 0.48 \\
& Rho: 0.240 & Rho: 0.222 & Rho: 0.220 \\
& p: 0.002 & p: 0.003 & p: 0.004 \\
\hline
\end{tabular}

Statistical analysis indicated that there was no relationship between the pulmonary symptoms, cutaneous and ocular symptoms and hematological parameters in patients who had presented with symptoms of rhinitis. On the other hand, a relationship was found between the nasal symptoms and the hematological parameters. When the rhinitis symptoms were analyzed individually, the duration of illness and $\mathrm{RBC}, \mathrm{Hb}$ and $\mathrm{Htc}$ values were found to be positively correlated in patients with nasal obstruction. The correlation of nasal symptoms and the duration of illness have been presented in Table 3. No relationship was found between the Platelet count and MPV and the severity and duration of symptoms.

Skin prick tests to grass mixture were positive in 48 $(51.1 \%)$ patients, to $\mathrm{D}$. farine in $16(17 \%)$, and to $\mathrm{D}$. Pteronyssinus in $35(37.2 \%)$. There was no significant relationship between the type of positive prick test and the hematologic parameters.

RBC, Hb, WBC and MPV were accepted as dependent variables in the regression analysis model, and allergens, duration of illness, skin prick test positivity, age and gender were accepted as independent variables, and the relationships were analyzed. In the both group, $\mathrm{RBC}$ and $\mathrm{Hb}$ were seen to be affected by duration of disease [for: $\mathrm{RBC} p=0.004, \mathrm{~B}=$ 4.627 (95\% CI:4.515-4.739) and for $\mathrm{Hb}: \mathrm{p}=0.011$ $\mathrm{B}=13.626(95 \% \mathrm{CI}: 3.268-13.983)]$ and not to be affected by allergen distribution. WBC was seen to decrease as the duration of illness prolonged in both allergic and non-allergic groups (Rho: -0.160 , p= 0.042).

\section{DISCUSSION}

In this study, the values of $\mathrm{RBC}, \mathrm{Hb}, \mathrm{Htc}, \mathrm{WBC}$, PLC, and MPV were found in normal range in patients who had presented with chronic rhinitis symptoms. Additionally, in correlation analysis, the duration of disease was positively correlated with $\mathrm{RBC}, \mathrm{Hb}$ and Htc in subgroup with nasal obstruction. Moreover, in regression analysis, the duration of disease was also an independent parameter of $\mathrm{RBC}$ and $\mathrm{Hb}$ in patients with AR.

Previously, Olcay et al. have been reported that MPV and PLC values in patients with bronchial asthma were significantly higher than controls. However, their study population size was very small (10 patients and 10 controls). ${ }^{9}$ On the other hand, haematologic parameters which obtained from complet blood count were analysed in neither chronic rhinitis nor allergic rhinitis. The best of our knowledge, this study is first showing that the values of RBC, Hb, Htc, WBC, PLC, and MPV were in normal range in patients with chronic rhinitis symptoms. 
Formerly, Carlson et al. found that polycythemia was independent of associated daytime hypoxia in nine patients with unexplained polycythemia fulfilled the criteria for sleep apnoea. ${ }^{10}$ In other study, Moore-Gillon et al. found that $25 \%$ of 20 patients with unexplained polycythemia suffered from nocturnal breathing disturbance. ${ }^{11}$ On the contrary, no patients with disordered nocturnal breathing were found in a study of 16 patients with apparent or relative polycythemia. ${ }^{12}$ But, compared with our study, these studies had very small study population size. Furhermore, they addressed neither the role of nasal obstruction nor the allergy. However, in our study, the duration of disease was positively correlated with $\mathrm{RBC}, \mathrm{Hb}$ and $\mathrm{Htc}$ in patient subgroup with nasal obstruction. Systemic inflammation may lead to changes in hematological parameters in both AR and non-allergic rhinitis. The second mechanism that may be effective on hematological parameters is nasal obstruction and related intermittent hypoxia. Ishii et al. emphasized the relationship between intermittent hypoxia and polycythemia in their experimental study. ${ }^{13}$

In the present study, in regression analysis, the duration of disease was independently associated with an increase in $\mathrm{RBC}$ and $\mathrm{Hb}$ values in patients with AR. Similarly, the duration of disease was independently associated with an increase in RBC, Htc and $\mathrm{Hb}$ values in patients with nasal obstruction. Therefore, it can be speculated that the increase in Htc, $\mathrm{Hb}$ and $\mathrm{RBC}$ values associated with the duration of symptoms that indicates the role of intermittent hypoxia in chronic rhinitis patients. Already, the relationship between allergy-related immunological mechanisms and erythrocyte count and the hemoglobin levels have not been explained.

Conclusion: In current study, the presence of nasal symptoms was found to be associated with the increases in $\mathrm{RBC}, \mathrm{Hb}$, and $\mathrm{Htc}$ values. In addition, the $\mathrm{RBC}$ and $\mathrm{Hb}$ values were affected by the duration of disease in the AR subgroup. Still, the longterm and prospective studies should be design to investigate the associations between hematological parameters and clinical parameters in nasal pathologies such as chronic rhinitis or allergic rhinitis.

\section{REFERENCES}

1. Karabulut $\mathrm{H}$, Karadağ AS, Acar B, et al. The evaluation of skin prick test results in Ankara Kecioren area according to meteorologic and demographic features. KBB-Forum 8: 1-9, 2009.

2. Shoenwetter WF. Allergic Rhinitis: epidemiology and natural history. Allergy Asthma Proc 21: 1-6, 2000.

3. Schatz M. A survey of the burden of allergic rhinitis in the USA. Allergy 62 (Suppl. 85): 9-16, 2007.

4. Eisensehr I, Noachtar S. Haematological aspects of obstructive sleep apnea. Sleep Med Rev 5: 207-221, 2001.

5. Thompson CB, Jakubowski JA, Quinn PG, et al. Platelet size and age determine platelet function independently. Blood 63: 1372-5, 1984.

6. Bath PMW, Butterworth RJ. Platelet size: Measurement, physiology and vascular disease. Blood Coag Fibrinol 7: 157-161, 1996.

7. Endler $G$, Klimesch A, Sunder-Plassmann $H$, et al. Mean platelet volume is an independent risk factor for myocardial infarction but not for coronary artery disease. Br J Haematol 117: 399-404, 2002.

8. Baser S, Ozkurt S, Topuz B, et al. Peak expiratory flow monitoring to screen for asthma in patients with allergic rihinitis. J Investig Allergol Clin Immunol 2007;17: 211-215, 2007.

9. Olcay I, Yardımcı S, Delibaşı T, Müftüoğlu O. Platelet functions in patients with allergic asthma. Turk J Haematol 18: 245-250, 2001.

10. Carlson JT, Hedner J, Fagerberg B, et al. Secondary polycythaemia associated with nocturnal apnea relationship not mediated by erythropoietin? J Int Med 231: 381-387, 1992.

11. Moore-Gillon JC, Treacher DF, Gaminara EJ, et al. Intermittent hypoxia in patients with unexplained polycythaemia. Br Med J 293: 588-590, 1986.

12. Messinezy M, Aubry S, O'Connel G, et al. Oxygen desaturation in apparent and relative polycythaemia. Br Med J 302: 216-217, 1991.

13. Ishii M, Iwamoto $T$, Nagai $A$, et al. Polycythemia and changes in erythropoietin concentration in rats exposed to intermittent hypoxia. Adv Exp Med Biol 662: 121-126, 2010.

\section{Correspondence \\ Dr. İsmail KARABULUT \\ Hacettepe Üniversitesi Tıp Fakültesi \\ Fizyoloji Anabilim Dalı \\ 06100 Sinhiye, ANKARA / TURKEY}

Tel: (+90.312) 3051567

e-mail: ikbulut2001@yahoo.com 